\title{
ODE TO AN EDUCATOR, WORK BASED LEARNER AND CHANGE AGENT
}

Robert Nelson

\section{Part I}

Solving real problems with skills learned elsewhere The capstone project is the proof of learning The capstone project is the proof of application The real evidence learners can collaborate and grow

No more learning only to neglect all later The assignments and exams - all done and forgotten Knowledge so painstakingly gained, tossed to the wind Its relationship to real life only fleetingly perceived

On what foundation have I built this expectation? Is it a proof base, or is it convenience? After all the teams I've seen implode I should know enough to avoid this road

Forming a team must be so easy - NO! Please sir, can you do it for us? We've never had to do it for ourselves We don't want the wrong people with us

Nothing could be worse than the wrong people...

The problem is not us - it is them We can get along with anyone at all We are adults - we always behave that way There is no problem that we cannot solve

Graduate Profile, Course Prescription - must collaborate they say

Your team of peers you get to choose

Sell yourselves you must - tell the real truth

Any particular team choice not guaranteed - sell well

The choice is made, the die is cast

It's up to you to make this work

Standard Operating Procedures - rules to live by next Negotiate them, make them operable - they are yours
The project is chosen - full speed ahead now You have formed, you have stormed, even normed You are invincible - what could possibly go wrong? Claims from the start don't match performance now

Human foibles come out to play every day It's not me, not us - it is them! They wrote and signed the rules with us Now they won't obey - not even a bit!

We want them out, we want them gone No matter how hard WE try, THEY fail The better our work, the worse theirs gets We cannot make this work, not at all

Like all good stories, this has two sides THEIR expectations are unreal, THEIR support never there We asked for help, but got only scorn We can't do it; can't afford to fail

Like a saviour in battered armour, help arrives Sometimes asked, sometimes not, but always willingly given I've been right here so many times before Will this team be the one that's different?

If I had any doubts, I would not try Just let them implode, let them hate away And then tell boss "Painful way to learn" People damaged, maybe destroyed, but learning objectives met...

I will not abandon them in time of need I know too well where my responsibilities lie If they only learn to depend on me I have failed them, and also failed me 
On my shoulders lie so many heavy loads

So many stakeholders have invested belief in me

That what I told them is absolutely true

"No matter what - I am here for you"

To help people voice out is a must

The less I know, the harder to help

I still must earn your trust you see

You must experience I will listen to everyone

Do you want a listening ear or a decider?

What do your rules allow me to do?

You cannot win if things stay as are

Conflict is so frustrating, although invaluable learning comes

l've read your riles, listened to you all

There is some wrong, there is some right

I can help you solve this problem now

If you are willing to work with me

If you depend only on me, we failed

You have not learned to resolve conflict yourselves

You have not appreciated how negative becomes positive

You have not understood your wisdom and power

The best resolution is one YOU created

You will believe in it more than mine

The process is what you created yourselves

I only guided from my knowledge and experience

Remember what you've done, and how it happened

What it felt like in mind and heart

You have done what once you thought impossible

Hold fast to this knowledge, precious beyond compare

Not every team will experience such negative conflict For others - not a care in the world

Every challenge is met, ever goal is achieved

Harmony abounded, but how much did they learn?

Have they learned more or less than others?

Do they KNOW why negative conflict avoided them?

Was it something they did, or only luck?

But most of all - could they repeat it?

The project has run its course; solutions delivered

The marks have been awarded, the prizes too

The institution is happy, Project Sponsor as well

Little do they know the price we paid...

For the learners the experience is finished now

They have survived, they have grown - it's over!

They never have to live this experience again

Their collaborative lessons learned are ones for life

Some race to forget; others promise to remember

Some memories will stay with a learner forever
Remembered with varying degrees of clarity and depth

A foundation to guide future decisions and actions

Did your experience go beyond mandated course outcomes?

Not by my design, but by your choices

Have you emerged stronger because of what happened?

You are more experienced to graduate with confidence

What of your life once graduation is done?

The real world is not like a textbook

People don't always behave in predictable, logical ways

You've experienced them at their best and worst

You've had to deal with every strange behaviour

Trying to respect the person different to you

Trying to understand the person they really are

Keeping sight on the project, not forgetting that

At the start, you thought the course impossible

It required things you knew you couldn't do

Now at the end, how effective are you?

Employers want to know; point to your project

"What you see didn't exist before our team

Let me tell you about the part I played

How I led, managed, encouraged, empathised, and supported

How I will show how effective I am"

If you want someone who really backs themselves Capable and sound, driven but yet still human

Someone who can see holistically, also act independently

I'm your best candidate. When do I start"?

\section{Part 2}

All things equal, the learner does this once

Soon they will forget my name and face

But each next trimester, I do it again

Each new cohort, the same lessons to learn

The same process to use, same challenges to face

True, incremental changes made, based on previous experiences

While l've evolved the process, I haven't checked in

With the Number One Person facilitating the experience

Insidious and unappreciated, my passion my potential burnout

I joke about this with each new lot

"For an effective strategy, Do As I Say

Do NOT Do As I Do (unless necessary)"

Your project is important; not your whole life

Know when to step out, take a break

Go and smell the sunshine whenever you need

Working with no breaks - not recommended (unless

unavoidable)" 
I'm not superhuman; should have taken my advice Should have been able to apply my own lessons I've a mission you see, important to me To develop and grow next generation problem solvers

Did my passion blind me? Maybe it did I never "turned off", always focused on projects Holistic, collaboratively worked (and assessed where possible) experiences

Empathising with my learners, but never with me

Was I a "Legend In My Own Mind"?

Did my multiple awards mean anything at all?

Did I expect far too much from myself?

Could I make the course what it should be?

Fast forward now to the adventure called DPP

Where, at last, I have my greenfield site

Freedom, encouragement to think beyond the conventional constraints

To create not a course but an experience

To apply my passion, know how, and creative flair

To redefine what is possible - because it is

To build on the best from the past

To imagine, inspire, guide, consult, evolve as necessary

I should take my own advice to reflect

That action without reason is most often poor

But when is the best time for this?

It depends whose expert view you love most

Schön and Mezirow have taught me to reflect

Before I do a thing - will it work?

When I am in the middle of the action?

Or when it's all over and outcomes achieved?

The lessons I learn from valid experiences had Some will be "good", others will be "bad" I must record them in some permanent form Their maximum value lies beyond this one context

What has been taught is what l've learned

Our shared collaborative experience - different but similar You taught me as much as I you

What I create is your legacy as well

But between us still lies one crucial difference...

You were "students" and this was still "school"

Project thinking was always part time for you

It mattered not a bit what I did

"School projects" would never be your "Number One"

You wondered at my passion, you really did

Sometimes you probably thought l'd lost the plot

Why so intense - why not chill out a little?

Like the Blues brothers, I'm on a mission

\section{Part 3}

To integrate into a holistic, realistic learning experience From whoa to go, people and project indivisible Capturing the serendipity and magic of collaboration

On a scale not commonly done - although possible

Where my mission ends, I am not sure Perhaps it has no end; goes on evermore As long as learners must know of collaboration Experience it in practice, not just in theory

A sobering thing, to think of my legacy

To pay it forward, in present and future

In gratitude for the many experiences l've shared

The great, the disappointing, even those that hurt

Some told me I could not do this

It wasn't needed; I wasn't good enough

There were times when I believed those words

When I let them beat me down (repeatedly)

They hurt me more than I let them see I would not give them that sad pleasure Deep within me, well hidden, lay my conviction That I still had value, something to contribute

My mahi now on a much wider stage Practitioner, learner - the line between roles has blurred

At once I am both; my being torn

I belong in both worlds, yet in neither

The imposter syndrome against which I do battle 'Justified by my coloured perceptions of past events Some days the imposter wins, some days me I have been through too much to capitulate

My mission is greater than me the individual The black dog of depression who haunts me Released through the reflective exercise called the ROL He shall not claim the victory he doesn't deserve

This critical mission is no longer mine alone It is a collaboration - it is us, we What I have conceived, now shared with others I am one voice, but can lead korero

My eyes and ears opened to new possibilities Many things I could never have dreamed alone The challenge excites me; I am accepted here The belief and encouragement of others supports me

Yes, I have hurt and I have grown

Our strength lies in our diversity and collaboration

You have not made me, any of you

You have shaped me, every one of you 
I am you, you are me, we are we

Collaborative learning and collaboratively assessed projects

our shared passion

If I have learned one transformational thing so far

It is this: I am truly part of we

Together we will achieve more than I ever could You are my soul mates, my mentors, my friends In your company I am permitted and expected to Challenge convention, provoke disobedient thoughts and incite rebellious actions

All in the sacred cause of experiential learning My comfort zone has become elastic - nay, dynamic I have found space filled with like minds I have come home...

\section{KEY THEMES WOVEN THROUGH THE ODE}

Having established the foundations of my collaborative Work-Based Learning journey thus far through verse, I'm now going to consider, in more detail, two critical themes both inherently and explicitly woven through it:

- change agency; and

- reflection through an autoethnographic lens.

My own Doctor of Professional Practice (DProfPrac or, informally, as above, 'DPP') journey started long before enrolling in the qualification. I moved from being a learner engaging with a course that is "Project Management" by another name, but with a significant focus on the development of leadership (self and others) skills in a collaborative context (New Zealand Qualifications Authority, 2002; New Zealand Qualifications Authority, 2018), to facilitating the same course. Having experienced the course from both sides has equipped me with the knowledge to be an effective change agent. It has also given me much to reflect on, which has inevitably found its way into other courses I have facilitated. The value of the learning has thus been multiplied many times over and benefitted a wider range of stakeholders both within and outside the teaching institution.

\section{CHANGE AGENCY}

A change agent is defined as "...the individual or group that undertakes the task of initiating and managing change in an organization..." (Lunenburg, 2010, p. I). This is a fairly typical definition of the term, to which it is possible to add other factors such as uncovering the causes of problems (Pascale \& Sternin, 2005), creation of a positive and integrative environment for change (van den Berg et al., 2019), collaboration (van der Heijden et al., 2015), the provision of technical knowledge and social support (McKinsey \& Company, 2017), and minimising the resistance to change (Gupta \& Singla, 2021). Whether they come from inside or outside the organisation, their role is to change the thinking and behaviour of individuals inside the organisation to some defined and desired state (Govindarajan, 2020).

When I went literally from being a student on a Friday to a teacher the following Monday, this last point was one that I taught in my various management courses. It was not reflective of how I saw myself. My students were customers of my organisation, but they did not belong to it in the same way I did as an employee. A 
change agent might manipulate me as an employee towards my employer's desired future state, but surely that was different to what I was doing with my students who would go on to be employed by many different organisations who were not hiring me as an external change agent.

It took some little time to appreciate that, as a teacher, I was - I am a change agent. This agency manifests itself in several critical ways:

- seeking to bring about change in the institution and the systems I have to work within to facilitate co-creating more authentic learning experiences;

- seeking to bring about change in commercial and non-commercial organisations by graduating learners who are not only capable of solving a diverse range of problems, but who are also capable of working collaboratively to do so;

- seeking to bring about change in individuals via increased self-efficacy when it comes to working collaboratively with others, whether in a leadership or followership role.

Bolam (1975, as cited in Badley, 1986) identified a number of specific roles played by a change agent in terms of what they deliver to the people who are the subject of the change process. In training people to collaborate, an essential skill for management of selves and others in a capstone project that exists mostly in the world outside the classroom, I would add other critical roles to Bolam's list:

- counsellor - being invited into learners' lives, sometimes outside the context of their project team, to help resolve issues negatively impacting their ability to take an effective part in their project teams;

- conflict manager - sometimes as a "court of last resort" where learners believed themselves unable to resolve intra-team and inter-team issues without external guidance.

A study by Stewart et al. (2018) found that, as much as process failures could be blamed for project failure, so could competence failures. Many of the cultural issues they highlighted revealed not only technical failures, but also failures of individuals to engage collaboratively within and across discipline areas. My own practice, therefore, has been to develop a culture within capstone cohorts that is essentially learner-centred, where I become a guide and facilitator rather than the authoritative fount of all knowledge they may have expected from a tutor.

Donnelly and Fitzmaurice (2005) identified the ability to work collaboratively to solve problems as an important outcome of project and problem-based learning scenarios. They further identified that such an approach actually required more rather than less tutor time being invested in a cohort to achieve desirable outcomes. It is not only the desire or willingness of the facilitator to deliver such a collaborative learning experience on its own that determines likely outcomes - as a change agent I must also work to change institutional systems such that the institution does not take this extra workload for granted and are instead able to meaningfully support it.

It is sometimes said of bureaucracies that it is easier to do something and ask for forgiveness later than to plan something and ask for permission. As a change agent, this is something I must be mindful of. Some boundaries are easier to push and more flexible than others. What I must never lose sight of, though, are the responsibilities I have to diverse stakeholder groups to ensure that authentic learning is not only relevant now, but also futureproofing as much as is practical participants in, and other beneficiaries of the learning experience. This leads to the second interwoven key theme: reflection on what happens and what the outcomes are. 


\section{REFLECTION THROUGH AN AUTOETHNOGRAPHIC LENS}

The autoethnographic lens enables me to see the world on my own terms; to be the hero of my own narrative, or the villain should that be appropriate. The distinction is important - I am forced to confront my own fallibility, my own 'normal human-ness' on a regular basis. As much as I like to think that my judgements are based on some sort of Mister Spock-like logic, I must acknowledge the role that emotion plays, consciously or otherwise. Buckley (2015) points out the need for beliefs about emotional influence to be triangulated - the difficulty as a practitioner is that my learners may not choose to reflect on the same events that I have reflected on. Add to that their reflections being produced as assessment pieces and not being perceived by them as part of an ongoing professional development strategy, and I must accept my reflections are likely to contain bias that cannot be easily countered.

A critical skill for an educator to develop as part of continuous professional development is that of reflection, yet little of my adult teaching training all those years ago focused on how to do this outside the context of the training course itself. There seemed to be an unspoken assumption that I already knew how to do this, which was never checked. Some reflection was enforced as a matter of institutional policy - the results summary at the end of a course, although this was more about identifying issues of student performance in order to explain their marks, with minimal emphasis on reflecting about my teaching practice. Reflection had been a compulsory component of my capstone experience as a student, but we weren't taught about the giants of reflective thinking - the likes of Mezirow (1990), Schön (1983), and Dewey (Dimova \& Kamarska, 2015) - or about how to apply their methods to our own experiences.

As facilitator of that same capstone project course, I decided that if the students were required to reflect formally on their own experience, I would do the same - a case of "one rule to rule them all." The writing would be to find a way to say what I know, to give voice to something that might otherwise not be described and captured; I would go further than that, though-I would share my thoughts with my capstone cohort after the end of each trimester, so they could know how I had been growing alongside them on, and learn from my experience, beyond the formal end of their capstone experience. Plack and Greenberg (2005) point to reflection as something that is simultaneously practised at multiple levels - dealing with the problem immediately in front of the practitioner while at the same time thinking about its potential causes, whether I am taking the most effective actions I can, and what the future implications of my decision are likely to be.

Having captured my reflections through events generic and common enough that participants other than me could not be identified, they can have another life as problem-solving tools. Munby (1989) identifies the importance of feedback as a part of Schön's reflective model and the way in which that allows me to reframe my understanding of events and outcomes. I would argue an important part of that reflective feedback (to me) is its authenticity. Its connection to ill-defined problems, even if the processes are relatively predictable; multiple sources and perspectives, collaboration and multiple possible outcomes (Pearce, 2016), means I am living in the same world my learners are experiencing, having similar reaction for (probably) similar reasons, and this gives value and credibility to the reflections.

Their permanence means I am creating an ever-growing library to which I can refer for dealing with future problems. The criticality of lived experiences is shown by Droege (2013) to be an important determinant of how memories are recalled and reassembled for conscious use. As a foundation-stone of my continuing professional development, these formal reflections formed an evolving journal allowing me to adopt a Janus perspective (Bates \& Wright, 2019), looking to the past and the future as necessary to understand the value of my present experiences. There is no single 'right' or 'wrong' answer to the questions prompted by my reflections - there are only answers that address particular circumstances at particular times, and which provide general guidance for facilitating future project teams. It is both my privilege and, I believe, my obligation to share such answers as I do have with learners and peers alike in order to multiply their value when they prompt others to think before they do. 


\section{FINAL THOUGHTS}

I have titled this article as an ode to a change agent. While I own the final thoughts that have given form and order to these words, I acknowledge they are not mine alone. As a lifelong learner and professional educator, they represent many years of mahi, many voices, much körero and many collaborations. They represent events deemed successes and failures. They represent relationships created, nurtured, and ended in various ways. They represent not only my growth as a collaborative Work-Based Learning practitioner to this point, but also the foundation of who I am yet to become. While they are not the only themes that could have been extracted from the ode they are, based on my own experience, the most critical when it comes to the success of workplace learning as a facilitator or as a learner. My experiences and my learning - these are my gifts to you to adopt, adapt and use as you will.

Rob Nelson trained as a printer, worked his way into management, later qualifying in management and then leadership as an adult student. He then embarked on a second career teaching management, and has significant experience in collaborative project-based learning.

Email: rob.nelson00।@gmail.com

\section{REFERENCES}

Badley, G. (1986). The teacher as change agent. Professional Development in Education, 12(3), 151-158.

Bates, S., \& Wright, V. (2019). Adopting a Janus perspective: moving forwards and backwards through our teacher professional experiences. International Journal of Lifelong Education, DOI: 10.1080/02601370.2019.1585394

Buckley, R. (2015). Autoethnography helps analyse emotions. Frontiers in Psychology, 6(209), I-3.

Dimova, Y., \& Kamarska, K. (20I5). Rediscovering John Dewey's model of learning through reflective inquiry. Problems of Education in the 21st Century, 63, 29-39.

Donnelly, R., \& Fitzmaurice, M. (2005). Collaborative project-based learning and problem-based learning in higher education: A consideration of tutor and student role in learner-focused strategies. In G. O'Neill, S. Moore \& B. McMullin (eds) Emerging issues in the practice of university learning and teaching (pp.87-98). Dublin: AISHE/HEA.

Droege, P. (2013). Memory and consciousness. Philosophie Scientiæ, 17(2), 17I-193.

Govindarajan, K. (March 19, 2020). Who is a change agent? Freshservice Blog. https://freshservice.com/change-agent-definitionroles-blog/

Gupta, S., \& Singla, A. (2021). Role of change agent in minimizing resistance and enhancing readiness for change. In S. Shruthi \& R. K. Gupta (Eds.), Perspectives on business management (Volume II) (pp.45-50). Archers \& Elevators Publishing House.

Lunenburg, F. (2010). Managing change: the role of the change agent. International Journal of Management, Business and Administration, 13(I), 2010.

McKinsey \& Company. (March 28, 2017). The change agent challenge. https://www.mckinsey.com/business-functions/operations/ our-insights/the-change-agent-challenge

Mezirow, J. (1990). How critical reflection triggers transformative learning. In J. Mezirow and Associates, eds., Fostering critical reflection in adulthood: a guide to transforming and emancipatory learning (pp. I-20), Jossey-Bass.

Munby, H. (1989). Reflection-in-action and reflection-on-action. Current Issues in Education, 9, 31-4I.

New Zealand Qualifications Authority. (2002). Prescription: 236 Applied Management. In New Zealand Diploma in Business Regulations Prescriptions. Wellington.

New Zealand Qualifications Authority. (2018). Prescription: 636 Applied Management. Wellington.

Pascale, R. T., \& Sternin, J. (May, 2005). Your company's secret change agents. Harvard Business Review. https://hbr.org/2005/05/ your-companys-secret-change-agents

Pearce, S. (2016). Authentic learning: What, why and how? e-Teaching April 2016 (10). 
Plack, M. T., \& Greenberg, L. (2005). The reflective practitioner: Reaching for excellence in practice. Pediatrics, I/6, I546-I552. DOI: 10.1542/peds.2005-0209

Schön, D. (1983). The reflective practitioner. Jossey-Bass.

Stewart, A., Nassif, A., \& Stewart, A. (2018). Education, a change agent for project failure? In J. Shiau, V. Vimonsatit, S. Yazdani, and A. Singh (Eds.), Streamlining information transfer between construction and structural engineering, ISEC Press.

van den Berg J., Zijp M. C., Vermeulen W. J. V., Witjes S. (2019). Identifying change agent types and its implications for corporate sustainability integration based on worldviews and contextual factors. Journal of Cleaner Production (2019). https://doi.org/10.1016/j.jclepro.2019.04.272

van der Heijden, H. R. M. A., Geldens, J. J. M., Beijaard, D., \& Popeijus, H. L. (June 2, 2015). Characteristics of teachers as change agents. Teachers and Teaching: theory and practice. DOI: 10.1080/13540602.2015.1044328 